\title{
Co-application of herbicides and insecticides in dry bean
}

\author{
Nader Soltani ${ }^{1 *}$, Robert E. Nurse ${ }^{2}$, Christy Shropshire ${ }^{1}$, Peter H. Sikkema ${ }^{1}$ \\ ${ }^{1}$ University of Guelph, Ridgetown Campus, Ridgetown, Canada; ${ }^{*}$ Corresponding Author: nsoltani@ridgetownc.uoguelph.ca \\ ${ }^{2}$ Agriculture and Agri-Food Canada, Harrow, Canada
}

Received 14 January 2012; revised 27 February 2012; accepted 7 March 2012

\begin{abstract}
Eight field trials were conducted from 2006 to 2008 at various locations in Ontario to evaluate the co-application of postemergence herbicides with cyhalothrin-lambda or dimethoate insecticides in cranberry and white bean. At 2 weeks after treatment, the addition of cyhalothrinlambda or dimethoate insecticides to sethoxydim, quizalofop-p-ethyl, bentazon, fomesafen and bentazon plus fomesafen did not increase injury at the Exeter and Ridgetown locations except for bentazon plus dimethoate which caused greater injury than bentazon alone $(2.9 \%$ vs $0.2 \%)$ in 2006. However at Harrow, the addition of dimethoate to quizalofop-p-ethyl increased injury ( $0 \%$ vs $4.9 \%$ ) in 2007 and the addition cyhalothrinlambda or dimethoate to sethoxydim increased injury in 2008 in dry bean. The addition of cyhalothrin-lambda to quizalofop-p-ethyl also increased injury ( $0 \%$ vs $4.5 \%$ ) in 2008 . There was no adverse effect on dry bean injury with other treatments at Harrow in 2007 or 2008. The addition of cyhalothrin-lambda or dimethoate to the herbicides evaluated did not have any adverse effect on plant height, shoot dry weight or yield of dry bean except for bentazon plus dimethoate which decreased shoot dry weight $20 \%$ compared to bentazon alone at Harrow in 2008. Based on these results, cyhalothrin-lambda or dimethoate can be tankmixed with sethoxydim, quizalofop-p-ethyl, bentazon, fomesafen and bentazon plus fomesafen when the optimum application timing of these herbicides and insecticides coincide.
\end{abstract}

Keywords: Cranberry Bean; Height; Herbicide Sensitivity; Injury; Tolerance; White Bean; Yield

\section{INTRODUCTION}

Dry bean (Phaseolus vulgaris L.) is an important high value agricultural crop grown in Ontario. In 2010, dry bean growers planted nearly 57,000 hectares and produced 129,000 MT of dry bean with a farm gate value of approximately $\$ 100,000,000$ [1]. Intensive agronomic practices, including effective integrated pest control management, are needed for profitable production of this important high value field crop. Growers often use postemergence (POST) herbicides such as sethoxydim, quizalofop-p-ethyl, bentazon, fomesafen and bentazon plus fomesafen for weed control in dry bean.

Sethoxydim and quizalofop-p-ethyl inhibit acetyl-CoA carboxylase (ACCase), the enzyme needed for fatty acid synthesis and subsequent production of phospholipids needed for cell membranes in plants. Sethoxydim and quizalofop-p-ethyl can provide effective control of annual and perennial grass species such as Panicum dichotomiflorum Michx. (fall panicum), Echinochloa crusgalli L. (barnyard grass), Setaria viridis (L.) Beauv. (green foxtail), Digitaria sanguinalis (L.) Scop. (large crabgrass), Panicum miliaceum L. (proso millet), Panicum capillare L. (witchgrass) and Elytrigia repens (L.) Nevski (quackgrass) [2,3].

Bentazon is a benzothiadiazole herbicide that can control broadleaved weeds such as Ambrosia artemisiifolia L. (common ragweed), Sinapis arvensis L. (wild mustard), Amaranthus retroflexus L. (redroot pigweed), Polygonum persicaria L. (ladysthumb), Chenopodium album L. (common lambsquarter), Abutilon theophrasti Medic. (velvetleaf), Raphanus raphanistrum L. (wild radish), Portulaca oleracea L. (purslane), Galinsoga ciliata (hairy galinsoga), Senecio vulgaris (common groundsel), Xanthium strumarium L. (cocklebur), Datura stramonium L. (jimsonweed), Capsella bursa-pastoris (L.) Medic (shepherdspurse) and Stellaria media (L.) Vill. (common chickweed) including group II and V resistant biotypes [2,3].

Fomesafen is a diphenyl ether herbicide that can control broadleaved weeds such as Sinapis arvensis, Amaranthus retroflexus, Ambrosia artemisiifolia, Polygonum persicaria, Xanthium strumarium and Solanum spp. (black nightshade) [2,3]. Bentazon in tank mix combina- 
tion with fomesafen can provide improved control of broadleaf weeds such as pigweed spp., ragweed spp., Solanum spp. and wild buckwheat (Polygonum convolvulus L. [2,3].

Common insect pests in dry bean in Ontario include potato leafhopper (Empoasca fabae), bean leaf beetle (Certoma trifurcata), Mexican bean beetle (Epilachna varivestis), western bean cutworm (Striacosta albicosta) and tarnished plant bug (Lygus lineolaris). Single or multiple foliar applications of cyhalothrin-lambda (Mata$\left.\operatorname{dor}^{\circledR}\right)$ and dimethoate $\left(\right.$ Lagon $\left.^{\circledR}\right)$ insecticides during the growing season are often used to effectively control these troublesome insects in dry bean [4].

Optimum application timing of postemergence herbicides and insecticides may coincide, however, currently there are no combinations of herbicides plus an insecticide labelled for use in dry bean grown in Ontario. Co-application of herbicides with an insecticide would allow growers to reduce the number of passes through the field thereby reducing fuel and labor costs, machinery depreciation, soil compaction, as well as mechanical damage to dry bean foliage [5-10].

There are no published data on the effects of co-application of cyhalothrin-lambda or dimethoate with sethoxydim, quizalofop-p-ethyl, bentazon, fomesafen and bentazon plus fomesafen in cranberry and white bean under Ontario environmental conditions. In addition, information on compatibility of sethoxydim, quizalofopp-ethyl, bentazon, fomesafen and bentazon plus fomesafen herbicides with cyhalothrin-lambda or dimethoate insecticides is very important to dry bean growers since incompatibility in the tank can result in significant crop injury and equipment damage as well as reduction in weed and insect control.

The objectives of this study, therefore, were to determine if the addition of an insecticide (cyhalothrinlambda or dimethoate) to sethoxydim, quizalofop-p-ethyl, bentazon, fomesafen and bentazon plus fomesafen would result in increased injury or yield loss in cranberry or white bean.

\section{MATERIALS AND METHODS}

Eight field studies were conducted over a three-year period (2006 to 2008) in major dry bean growing areas in Ontario, Canada. Locations included the University of Guelph, Huron Research Station near Exeter (2006, 2007, 2008), Agriculture and Agri-Food Research Farm near Harrow (2007, 2008), and University of Guelph, Ridgetown Campus near Ridgetown (2006, 2007, 2008). The soil type at Exeter was a Brookston clay loam soil, at Harrow was a Honeywood silt loam soil, and at Ridgetown was a Brookston loam soil. Seedbed preparation at all sites consisted of fall moldboard plowing followed by three passes with a field cultivator in the spring.

The experiments were established as a split-plot design arranged in a completely randomized block with four replications. The main plots were 18 treatments as listed in Table 1 and the sub-plots were two market classes of dry bean (cranberry and white bean). Plots were $3 \mathrm{~m}$ wide (4 rows spaced $0.75 \mathrm{~m}$ apart) and $10 \mathrm{~m}$ long at Exeter and $8 \mathrm{~m}$ long at Ridgetown and Harrow. Within each plot there were two rows of cranberry ("Etna") and white ("OAC REX") beans. Beans were planted in late May to early June of each year.

Herbicide applications were made with a $\mathrm{CO}_{2}$-pressurized backpack sprayer calibrated to deliver $200 \mathrm{~L} \cdot \mathrm{ha}^{-1}$ of spray solution at a pressure of $241 \mathrm{kPa}$ using low drift nozzles. Treatments were applied at the $1-3$ trifoliate leaf stage. All plots were maintained weed-free during the season with hand hoeing and cultivation as required.

Crop injury was evaluated visually 1, 2 and 4 weeks after treatment (WAT) using a scale of 0 to $100 \%$ where a rating of 0 was defined as no visible plant injury and a rating of 100 was defined as plant death. At 4 WAT, a $1 \mathrm{~m}$

Table 1. Herbicide and insecticide treatment combinations and rates.

\begin{tabular}{|c|c|c|}
\hline & Treatment & $\begin{array}{c}\text { Rate } \\
\mathrm{g} \cdot \mathrm{ai} \cdot \mathrm{ha}^{-1}\end{array}$ \\
\hline 1 & Untreated check & 0 \\
\hline 2 & Sethoxydim ${ }^{\mathrm{a}}$ & 500 \\
\hline 3 & Quizalofop-p-ethyl $^{\mathrm{b}}$ & 72 \\
\hline 4 & Bentazon & 1080 \\
\hline 5 & Fomesafen $^{c}$ & 240 \\
\hline 6 & Bentazon + fomesafen & $840+140$ \\
\hline 7 & Dimethoate & 480 \\
\hline 8 & Cyhalothrinlambda & 10 \\
\hline 9 & Sethoxydim + dimethoate ${ }^{\mathrm{a}}$ & $500+480$ \\
\hline 10 & Sethoxydim + cyhalothrinlambda $^{\mathrm{a}}$ & $500+10$ \\
\hline 11 & Quizalofop-p-ethyl + dimethoate $^{\mathrm{b}}$ & $72+480$ \\
\hline 12 & Quizalofop-p-ethyl + cyhalothrinlambda ${ }^{\mathrm{b}}$ & $72+10$ \\
\hline 13 & Bentazon + dimethoate & $1080+480$ \\
\hline 14 & Bentazon + cyhalothrinlambda & $1080+10$ \\
\hline 15 & Fomesafen + dimethoate ${ }^{c}$ & $240+480$ \\
\hline 16 & Fomesafen + cyhalothrinlambda $^{c}$ & $240+10$ \\
\hline 17 & Bentazon + fomesafen + dimethoate & $840+140+480$ \\
\hline 18 & Bentazon + fomesafen + cyhalothrinlambda & $840+140+10$ \\
\hline
\end{tabular}

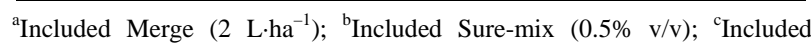
non-ionic surfactant $(0.25 \% \mathrm{v} / \mathrm{v})$. 
section of row for each cultivar was hand harvested at the ground level, oven dried at $60^{\circ} \mathrm{C}$ to a constant moisture and the dry weight was recorded. Ten plants per plot were randomly selected and the height from the soil surface to the highest growing point was measured 6 WAT. Yield and seed moisture content were measured at crop maturity by combining the remaining $9 \mathrm{~m}$ from each plot at Exeter and $7 \mathrm{~m}$ from each plot at Ridgetown and Harrow. Crops were considered physically mature when $90 \%$ of pods in the untreated plots of each cultivar had turned from green to a golden colour. All yields were adjusted to $18 \%$ moisture.

All data were subjected to analysis of variance (ANOVA). Data were analyzed using the PROC MIXED procedure of Statistical Analysis Systems [11]. Variances were partitioned into the fixed effects of herbicide/insecticide treatment, dry bean market class and their interaction, and the random effects of environment (location and year combinations), replication (within environment) and the interactions with fixed effects. Significance of fixed effects was tested using F-tests and random effects were tested using a Z-test of the variance estimate. The assumptions of the variance analyses (random, homogeneous, normal distribution of error) were confirmed using residual plots and the Shapiro-Wilk statistic. To meet the assumptions of the variance analysis, percent visual injury and shoot dry weight were subjected to log transformation or square root transformation as required [12]. Data were compared on the transformed scale and were converted back to the original scale for presentation of results. Yield data did not require any transformation. Treatments were compared using planned contrasts (Table 2). The Type I error was set at $\mathrm{P}<0.05$ for all statistical comparisons.

\section{RESULTS AND DISCUSSION}

Data were pooled and averaged over environments when statistically possible (i.e. environment $\times$ treatment $\times$ market class interaction was not significant) in Tables 3-6. Dry bean market classes were pooled and averaged when statistically possible (i.e. treatment $\times$ market class interaction was not significant) in Tables 3-6. There were no visible incompatibility problems in respect to the spray solution or application with the various herbicide plus insecticide tankmixes evaluated in this study.

\subsection{Visible Injury}

At 1 WAT, the addition of dimethoate insecticide to bentazon or bentazon plus fomesafen resulted in increased visible injury in cranberry and white bean (Table 3). However, the addition of cyhalothrin-lambda insecticide to bentazon and bentazon plus fomesafen did not increase injury in dry bean. Also, the addition of cyhalothrin-lambda or dimethoate insecticides to sethoxydim, quizalofop-p-ethyl or fomesafen did not result in in an increase in injury in cranberry or white bean.

At 2 WAT, the addition of cyhalothrin-lambda or dimethoate insecticides to sethoxydim, quizalofop-p-ethyl, bentazon, fomesafen or bentazon plus fomesafen did not increase injury at the Exeter and Ridgetown locations except for bentazon plus dimethoate insecticide which caused greater injury than bentazon alone ( $0.2 \%$ vs $2.9 \%)$ in 2006 (Table 4). However at Harrow, the addition of dimethoate insecticide to quizalofop-p-ethyl increased injury (0\% vs 4.9\%) in 2007 and the addition cyhalothrin-lambda or dimethoate insecticides to sethoxydim increased injury in 2008 in dry bean. The addition of cyhalothrin-lambda to quizalofop-p-ethyl also increased injury ( $0 \%$ vs $4.5 \%$ ) in 2008 . There was no adverse effect on dry bean injury with the other herbicide/insecticide combinations at Harrow in 2007 or 2008 (Table 4).

At 4 WAT, the addition of cyhalothrin-lambda or dimethoate insecticides to sethoxydim, quizalofop-p-ethyl, bentazon, fomesafen and bentazon plus fomesafen did

Table 2. Contrasts planned for treatment comparisons.

\begin{tabular}{clc}
\hline Contrast label & \multicolumn{1}{c}{ Contrast description } & Treatments \\
\hline S vs S + D & sethoxydim vs sethoxydim + dimethoate & 2 vs 9 \\
S vs S + C & sethoxydim vs sethoxydim + cyhalothrinlambda & 2 vs 10 \\
Q vs Q + D & quizalofop-p-ethyl vs quizalofop-p-ethyl + dimethoate & 3 vs 11 \\
Q vs Q + C & quizalofop-p-ethyl vs quizalofop-p-ethyl + cyhalothrinlambda & 3 vs 12 \\
B vs B + D & bentazon vs bentazon + dimethoate & 4 vs 13 \\
B vs B + C & bentazon vs bentazon + cyhalothrinlambda & 4 vs 14 \\
F vs F + D & fomesafen vs fomesafen + dimethoate & 5 vs 15 \\
F vs F + C & fomesafen vs fomesafen + cyhalothrinlambda & 5 vs 16 \\
BF vs BF + D & bentazon + fomesafen vs bentazon + fomesafen + dimethoate & 6 vs 17 \\
BF vs BF + C & bentazon + fomesafen vs bentazon + fomesafen + cyhalothrinlambda & 6 vs 18 \\
\hline
\end{tabular}


Table 3. Contrasts comparing edible bean injury 1 week after treatment (WAT) for herbicide and insecticide treatment combinations at Exeter, Harrow and Ridgetown, $\mathrm{ON}^{\mathrm{a}}$.

\begin{tabular}{|c|c|c|c|c|}
\hline \multirow{3}{*}{ Treatment comparison } & \multicolumn{4}{|c|}{ Injury at 1 WAT $\%$} \\
\hline & \multirow{2}{*}{$\mathrm{E} 1, \mathrm{R} 1$} & \multicolumn{2}{|c|}{ E2, H2, R2 } & \multirow{2}{*}{ E3, R3 } \\
\hline & & cranberry & white & \\
\hline $\mathrm{S}$ vs $\mathrm{S}+\mathrm{D}$ & 0 vs 0.3 & 0 vs 0 & 0 vs 0 & 0 vs 0.1 \\
\hline $\mathrm{S}$ vs $\mathrm{S}+\mathrm{C}$ & 0 vs 0.2 & 0 vs 0 & 0 vs 0 & 0 vs 0.4 \\
\hline Q vs Q + D & 2.9 vs 2.6 & 0.3 vs 0 & 0.3 vs 0.3 & 2.4 vs 2.6 \\
\hline $\mathrm{Q}$ vs $\mathrm{Q}+\mathrm{C}$ & 2.9 vs 3.0 & 0.3 vs 0.2 & 0.3 vs 1.1 & 2.4 vs 2.6 \\
\hline $\mathrm{B}$ vs $\mathrm{B}+\mathrm{D}$ & 1.6 vs $4.4^{*}$ & 2.8 vs $8.1^{*}$ & 0.9 vs $7.4^{*}$ & 2.7 vs $7.1^{*}$ \\
\hline $\mathrm{B}$ vs $\mathrm{B}+\mathrm{C}$ & 1.6 vs 1.6 & 2.8 vs 2.1 & 0.9 vs 1.1 & 2.7 vs 2.6 \\
\hline F vs $F+D$ & 1.2 vs 1.2 & 0 vs 0 & 0 vs 0 & 0 vs 0.2 \\
\hline $\mathrm{F}$ vs $\mathrm{F}+\mathrm{C}$ & 1.2 vs 1.6 & 0 vs 0 & 0 vs 0 & 0 vs 0 \\
\hline $\mathrm{BF}$ vs $\mathrm{BF}+\mathrm{D}$ & 2.1 vs 2.9 & 2.1 vs $7.1^{*}$ & 1.0 vs $4.3^{*}$ & 2.2 vs $6.3^{*}$ \\
\hline $\mathrm{BF}$ vs $\mathrm{BF}+\mathrm{C}$ & 2.1 vs 2.1 & 2.1 vs 1.5 & 1.0 vs 0.9 & 2.2 vs 3.0 \\
\hline
\end{tabular}

*Denotes significance at P < 0.05; a Abbreviations: B, bentazon; C, cyhalothrinlambda; D, dimethoate; DAT, days after treatment; E1, Exeter 2006; E2, Exeter 2007; E3, Exeter 2008; F, fomesafen; H2, Harrow 2008; Q, quizalofop-p-ethyl; R1, Ridgetown 2006; R2, Ridgetown 2007; R3, Ridgetown 2008; S, sethoxydim; WAT, weeks after treatment.

Table 4. Contrasts comparing edible bean injury 2 weeks after treatment (WAT) for herbicide and insecticide treatment combinations at Exeter, Harrow and Ridgetown, $\mathrm{ON}^{\mathrm{a}}$.

\begin{tabular}{|c|c|c|c|c|c|}
\hline \multirow{3}{*}{$\begin{array}{c}\text { Treatment } \\
\text { comparison }\end{array}$} & \multicolumn{5}{|c|}{ Injury at 2 WAT \% } \\
\hline & \multirow{2}{*}{ E1, R1 } & \multicolumn{2}{|c|}{ E2-3, R2-3 } & \multirow{2}{*}{ H1 } & \multirow{2}{*}{ H2 } \\
\hline & & cranberry & white & & \\
\hline S vs $S+D$ & 0 vs 0 & 0 vs 0 & 0 vs 0 & 0 vs 1.8 & 0 vs $5.2^{*}$ \\
\hline $\mathrm{S}$ vs $\mathrm{S}+\mathrm{C}$ & 0 vs 0 & 0 vs 0 & 0 vs 0 & 0 vs 2.0 & 0 vs $6.3^{*}$ \\
\hline $\mathrm{Q}$ vs $\mathrm{Q}+\mathrm{D}$ & 1.4 vs 0.9 & 0.5 vs 0.5 & 0.4 vs 0.4 & 0 vs $4.9^{*}$ & 0 vs 1.8 \\
\hline $\mathrm{Q}$ vs $\mathrm{Q}+\mathrm{C}$ & 1.4 vs 1.6 & 0.5 vs 0.5 & 0.4 vs 0.4 & 0 vs 2.0 & 0 vs $4.5^{*}$ \\
\hline$B$ vs B + D & 0.2 vs $2.9^{*}$ & 1.5 vs 1.8 & 0.7 vs 0.9 & 0.5 vs 0.5 & 0 vs 0 \\
\hline $\mathrm{B}$ vs $\mathrm{B}+\mathrm{C}$ & 0.2 vs 0.3 & 1.5 vs 1.0 & 0.7 vs 0.2 & 0.5 vs 0 & 0 vs 0 \\
\hline $\mathrm{F}$ vs $\mathrm{F}+\mathrm{D}$ & 0.1 vs 0 & 0 vs 0.1 & 0 vs 0 & 6.0 vs 1.3 & 0 vs 0 \\
\hline $\mathrm{F}$ vs $\mathrm{F}+\mathrm{C}$ & 0.1 vs 0.2 & 0 vs 0 & 0 vs 0 & 6.0 vs $0^{*}$ & 0 vs 0 \\
\hline $\mathrm{BF}$ vs $\mathrm{BF}+\mathrm{D}$ & 0.3 vs 0.5 & 1.1 vs 1.6 & 0.3 vs 0.6 & 2.9 vs 1.0 & 0 vs 0 \\
\hline $\mathrm{BF}$ vs BF + C & 0.3 vs 0.6 & 1.1 vs 1.2 & 0.3 vs 0.4 & 2.9 vs 0 & 0 vs 0 \\
\hline
\end{tabular}

*Denotes significance at P < 0.05; ${ }^{*}$ Abbreviations: B, bentazon; C, cyhalothrinlambda; D, dimethoate; DAT, days after treatment; E1, Exeter 2006; E2, Exeter 2007; E3, Exeter 2008; F, fomesafen; H1, Harrow 2007; H2, Harrow 2008; Q, quizalofop-p-ethyl; R1, Ridgetown 2006; R2, Ridgetown 2007; R3, Ridgetown 2008; S, sethoxydim; WAT, weeks after treatment.

not increase injury at Exeter and Ridgetown locations except for quizalofop-p-ethyl plus dimethoate insecticide which caused greater injury than quizalofop-p-ethyl alone in white bean at Ridgetown in 2008 (Table 5). At Harrow, the addition of cyhalothrin-lambda or dimetho- ate insecticides to sethoxydim, quizalofop-p-ethyl, bentazon, fomesafen and bentazon plus fomesafen did not increase dry bean injury in 2007 (data not shown) but the addition cyhalothrin-lambda or dimethoate insecticides to sethoxydim or quizalofop-p-ethyl increased dry bean 
Table 5. Contrasts comparing edible bean injury and dry weight 4 weeks after treatments (WAT) for herbicide and insecticide treatment combinations at Exeter, Harrow and Ridgetown, $\mathrm{ON}^{\mathrm{a}}$.

\begin{tabular}{|c|c|c|c|c|c|}
\hline \multirow{3}{*}{$\begin{array}{l}\text { Treatment } \\
\text { comparison }\end{array}$} & \multicolumn{3}{|c|}{ Injury \% } & \multirow{2}{*}{\multicolumn{2}{|c|}{ Dry weight $\mathrm{g} \cdot \mathrm{m}^{-2}$ row }} \\
\hline & \multirow{2}{*}{$\mathrm{H} 2$} & \multicolumn{2}{|c|}{ R3 } & & \\
\hline & & cranberry & white & E1-3, R1-3 & H1-2 \\
\hline $\mathrm{S}$ vs $\mathrm{S}+\mathrm{D}$ & 0 vs $0.9^{*}$ & 0 vs 0 & 0 vs 0 & 193 vs 210 & 149 vs 135 \\
\hline $\mathrm{S}$ vs $\mathrm{S}+\mathrm{C}$ & 0 vs $2.5^{*}$ & 0 vs 0 & 0 vs 0 & 193 vs 212 & 149 vs 122 \\
\hline Q vs Q + D & 0 vs $2.3^{*}$ & 1.2 vs 1.5 & 0 vs $0.2^{*}$ & 204 vs 209 & 134 vs 138 \\
\hline $\mathrm{Q}$ vs $\mathrm{Q}+\mathrm{C}$ & 0 vs $2.5^{*}$ & 1.2 vs $0.8^{*}$ & 0 vs 0 & 204 vs 208 & 134 vs 136 \\
\hline $\mathrm{B}$ vs $\mathrm{B}+\mathrm{D}$ & 0 vs 0 & 0 vs 0 & 0 vs 0 & 192 vs 201 & 146 vs $117^{*}$ \\
\hline $\mathrm{B}$ vs $\mathrm{B}+\mathrm{C}$ & 0 vs 0 & 0 vs 0 & 0 vs 0 & 192 vs 202 & 146 vs 134 \\
\hline F vs $F+D$ & 0 vs 0 & 0 vs 0 & 0 vs 0 & 195 vs $223^{*}$ & 133 vs 134 \\
\hline $\mathrm{F}$ vs $\mathrm{F}+\mathrm{C}$ & 0 vs 0 & 0 vs 0 & 0 vs 0 & 195 vs 209 & 133 vs 117 \\
\hline $\mathrm{BF}$ vs $\mathrm{BF}+\mathrm{D}$ & 0 vs 0 & 0 vs 0 & 0 vs 0 & 195 vs 189 & 123 vs 137 \\
\hline $\mathrm{BF}$ vs $\mathrm{BF}+\mathrm{C}$ & 0 vs 0 & 0 vs 0 & 0 vs 0 & 195 vs 195 & 123 vs 148 \\
\hline
\end{tabular}

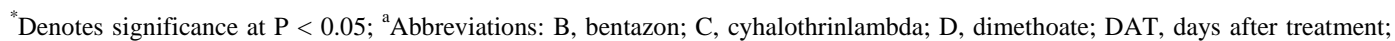
E1, Exeter 2006; E2, Exeter 2007; E3, Exeter 2008; F, fomesafen; H1, Harrow 2007; H2, Harrow 2008; Q, quizalofop-p-ethyl; R1, Ridgetown 2006; R2, Ridgetown 2007; R3, Ridgetown 2008; S, sethoxydim; WAT, weeks after treatment.

Table 6. Contrasts comparing edible bean yield for herbicide and insecticide treatment combinations at Exeter, Harrow and Ridgetown, $\mathrm{ON}^{\mathrm{a}}$.

\begin{tabular}{|c|c|c|c|c|c|c|}
\hline \multirow{3}{*}{$\begin{array}{l}\text { Treatment } \\
\text { comparison }\end{array}$} & \multicolumn{6}{|c|}{ Yield MT ha ${ }^{-1}$} \\
\hline & \multirow{2}{*}{ E1, R1 } & \multirow{2}{*}{ E2-3 } & \multicolumn{2}{|c|}{ H1-2 } & \multirow{2}{*}{$\mathrm{R} 2$} & \multirow{2}{*}{ R3 } \\
\hline & & & cranberry & white & & \\
\hline S vs $\mathrm{S}+\mathrm{D}$ & 2.58 vs 2.75 & 1.89 vs 2.02 & 2.78 vs 2.58 & 2.87 vs 3.08 & 2.24 vs 2.25 & 2.51 vs 2.28 \\
\hline $\mathrm{S}$ vs $\mathrm{S}+\mathrm{C}$ & 2.58 vs 2.77 & 1.89 vs 2.00 & 2.78 vs 2.56 & 2.87 vs 3.06 & 2.24 vs 2.28 & 2.51 vs 2.17 \\
\hline $\mathrm{Q}$ vs $\mathrm{Q}+\mathrm{D}$ & 2.45 vs 2.63 & 2.01 vs 2.04 & 2.56 vs 2.64 & 3.26 vs 2.89 & 2.30 vs 2.46 & 3.01 vs 2.49 \\
\hline $\mathrm{Q}$ vs $\mathrm{Q}+\mathrm{C}$ & 2.45 vs 2.58 & 2.01 vs 2.17 & 2.56 vs 2.54 & 3.26 vs 3.24 & 2.30 vs 2.26 & 3.01 vs 2.61 \\
\hline B vs B + D & 2.62 vs 2.78 & 1.94 vs 2.05 & 2.47 vs 2.59 & 2.71 vs 3.01 & 2.48 vs 2.23 & 2.17 vs 2.69 \\
\hline $\mathrm{B}$ vs $\mathrm{B}+\mathrm{C}$ & 2.62 v s2.79 & 1.94 vs 2.11 & 2.47 vs 2.47 & 2.71 vs 2.78 & 2.48 vs 2.28 & 2.17 vs 2.11 \\
\hline F vs F + D & 2.52 vs $2.80^{*}$ & 1.94 vs 2.18 & 2.57 vs 2.56 & 2.90 vs 2.92 & 2.25 vs 2.33 & 2.27 vs 2.40 \\
\hline $\mathrm{F}$ vs $\mathrm{F}+\mathrm{C}$ & 2.52 vs 2.71 & 1.94 vs 2.15 & 2.57 vs 2.70 & 2.90 vs 3.02 & 2.25 vs 2.21 & 2.27 vs 2.64 \\
\hline $\mathrm{BF}$ vs $\mathrm{BF}+\mathrm{D}$ & 2.59 vs 2.70 & 1.92 vs 2.04 & 2.46 vs 2.69 & 3.22 vs 3.13 & 2.37 vs 2.32 & 2.46 vs 2.67 \\
\hline $\mathrm{BF}$ vs $\mathrm{BF}+\mathrm{C}$ & 2.59 vs 2.76 & 1.92 vs 2.01 & 2.46 vs $2.83^{*}$ & 3.22 vs 3.04 & 2.37 vs 2.33 & 2.46 vs 2.38 \\
\hline
\end{tabular}

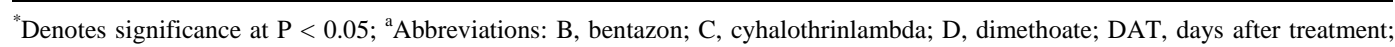
E1, Exeter 2006; E2, Exeter 2007; E3, Exeter 2008; F, fomesafen; H1, Harrow 2007; H2, Harrow 2008; Q, quizalofop-p-ethyl; R1, Ridgetown 2006; R2, Ridgetown 2007; R3, Ridgetown 2008; S, sethoxydim; WAT, weeks after treatment.

injury in 2008 (Table 5). In other studies, VanGessel et al. [13] reported $3 \%$ to $20 \%$ injury of dry bean with bentazon applied POST. However, other studies have shown less than 3\% injury in black bean and less than 2\% injury in cranberry bean with bentazon applied POST at 1080 $\mathrm{g} \cdot \mathrm{ha}^{-1}$ [14]. Burnside et al. [15] reported as much as $11 \%$ 
injury when sethoxydim was applied POST in combination with imazethapyr or acifluorfen and bentazon. Other studies have reported minimal injury with fomesafen applied POST in tank mix with other herbicides [14].

\subsection{Plant Height and Shoot Dry Weight}

The addition of cyhalothrin-lambda or dimethoate insecticides to sethoxydim, quizalofop-p-ethyl, bentazon, fomesafen or bentazon plus fomesafen did not have any adverse effect on plant height (data not shown) and shoot dry weight of dry bean except for bentazon plus dimethoate insecticide which decreased shoot dry weight 20\% compared to bentazon alone at Harrow in 2008 (Table 5). Results are similar to other studies that have shown sethoxydim, quizalofop-p-ethyl, bentazon, fomesafen and bentazon plus fomesafen cause no reduction in biomass of dry bean [13,14,16].

\subsection{Yield}

The addition of cyhalothrin-lambda or dimethoate insecticides to sethoxydim, quizalofop-p-ethyl, bentazon, fomesafen or bentazon plus fomesafen did not have any adverse effect on yield of cranberry and white bean under the various environments evaluated (Table 6). In other studies, herbicides such as sethoxydim, quizalofopp-ethyl, bentazon, fomesafen and bentazon plus fomesafen caused no adverse effect on yield of dry bean [13, $14,16,17]$. Blackshaw et al. [18] also reported no yield reduction in dry bean with the POST application of bentazon. However, Wall [19] found up to 21\% yield reduction in white navy bean with bentazon applied POST. Burnside et al. [15] reported no adverse effect on yield of dry bean when sethoxydim was applied POST in combination with imazethapyr or acifluorfen and bentazon.

\section{CONCLUSION}

Based on this research, the addition of cyhalothrinlambda or dimethoate insecticides to sethoxydim, quizalofop-p-ethyl, bentazon, fomesafen or bentazon plus fomesafen herbicides caused minimal injury in cranberry and white bean under various environments evaluated. Injury was minimal with no adverse effect on dry bean height, shoot dry weight and yield. Therefore, cyhalothrin-lambda or dimethoate insecticides can be safely tankmixed with sethoxydim, quizalofop-p-ethyl, bentazon, fomesafen or bentazon plus fomesafen when optimum application timing coincides.

\section{ACKNOWLEDGEMENTS}

The authors would like to acknowledge Todd Cowan for his expertise and technical assistance in these studies. Funding for this project was provided by the Ontario White Bean Producers, Ontario Coloured
Bean Growers Association, and the CanAdvance program of Agricultural Adaptation Council.

\section{REFERENCES}

[1] McGee, B. (2011) Estimated area, yield, production and farm value of specified field crops, Ontario, 2001-2010, (metric units).

http://www.omafra.gov.on.ca/english/stats/crops/estimate _metric.htm

[2] [OMAFRA] Ontario Ministry of Agriculture, Food, and Rural Affairs (2010) Guide to weed control. Publication 75, Toronto.

[3] Senseman, S.A. (2007). Herbicide handbook. 9th Edition, Champaign.

[4] [OMAFRA] Ontario Ministry of Agriculture, Food and Rural Affairs (2009) Agronomy guide for field crops. Publication 811, Toronto.

[5] Grichar, J.W. and Prostko, E.P. (2009) Effect of glyphosate and fungicide combinations on weed control in soybeans. Crop Protection, 28, 619-622. doi:10.1016/j.cropro.2009.03.006

[6] Jordan, D.L., Culpepper, A.S., Grichar, W.J., TredawayDucar, J., Brecke, B.J. and York, A.C. (2003) Weed control with combinations of selected fungicides and herbicides applied postemergence to peanut (Arachis hypogaea L.). Peanut Science, 30, 1-8. doi:10.3146/pnut.30.1.0001

[7] Jordan, D.L., Johnson, D. and York, A.C. (2006) Influence of foliar fertilizers and pesticides on efficacy of selected postemergence herbicides. Weed Science Society of America, 46, 38.

[8] Lancaster, S.H., Jordan, D.L., Brandenburg, R.L., Royal, B., Shew, B., Bailey, J., Curtis, V., York, A.C., Wilcut, J.W., Beam, J., Prostko, E., Culpepper, A.S., Grey, T., Johnson III, C., Kemerait, R., Brecke, B., McDonald, G., Tredaway-Ducar, J., College, B. and Wall, B. (2005) Tank mixing chemicals applied to peanut crops: Are the chemicals compatible? Extension Bulletin No. AGW653, North Carolina Cooperative Extension Service.

[9] Lancaster, S.H., Jordan, D.L., Spears, J.F., York, A.C., Wilcut, J.W., Monks, D.W., Batts, R.B. and Brandenburg, R.L. (2005) Sicklepod (Senna obtusifolia) control and seed production after 2,4-DB applied alone and with fungicides or insecticides. Weed Technology, 19, 451-455. doi:10.1614/WT-04-227R

[10] Robinson, D.E., Soltani, N., Hamill, A.S. and Sikkema, P.H. (2006) Weed control in processing tomato ( $L y$ copersicon esculentum) with rimsulfuron and thifensulfuron applied alone or with chlorothalonil or copper pesticides. HortScience, 41, 1295-1297.

[11] [SAS] Statistical Analysis Systems (2008) The SAS system. Version 9.2, Statistical Analysis Systems Institute, Cary.

[12] Bartlett, M.S. (1947) The use of transformations. Biometrics, 3, 39-52. doi:10.2307/3001536

[13] VanGessel, J.M., Monks, W.D. and Quintin, R.J. (2000) Herbicides for potential use in lima bean (Phaseolus lu- 
natus) production. Weed Technology, 14, 279-286. doi:10.1614/0890-037X(2000)014[0279:HFPUIL]2.0.CO ;2

[14] Soltani, N., Bowley S. and Sikkema P.H. (2005) Responses of black and cranberry beans (Phaseolus vulgaris) to postemergence herbicides. Crop Protection, 24, 15-21. doi:10.1016/j.cropro.2004.06.003

[15] Burnside, O.C., Ahrens W.H., Holder B.J., Wiens, M.J., Johnson, M.M. and Ristau E.A. (1994) Efficacy and economics of various mechanical plus chemical weed control systems in dry beans (Phaseolus vulgaris). Weed Technology, 8, 238-244.

[16] Sikkema, P.H., Soltani N., Shropshire C. and Cowan. T. (2004) Tolerance of white beans to postemergence broadleaf herbicides. Weed Technology, 18, 893-901.

$$
\text { doi:10.1614/WT-03-043R3 }
$$

[17] Soltani, N. and Sikkema, P.H. (2005) White bean (Phaseolus vulgaris) tolerance to preplant-incorporated herbicides. Weed Biology and Management, 5, 35-38. doi:10.1111/j.1445-6664.2005.00153.x

[18] Blackshaw, R.E., Molnar, J.L., Muendel, H.H., Saindon, G. and Li, X. (2000) Integration of cropping practices and herbicides improves weed management in dry bean $(P h-$ aseolus vulgaris). Weed Technology, 14, 327-336. doi:10.1614/0890-037X(2000)014[0327:IOCPAH]2.0.CO ;2

[19] Wall, D.A. (1995) Bentazon tank-mixtures for improved redwood pigweed (Amaranthus retroflexus) and common lambsquarters (Chenopodium album) control in navy beans. Weed Technology, 9, 610-616. 